\title{
Augmented reality-assisted pedicle screw insertion: a cadaveric proof-of-concept study
}

TO THE READERSHIP: A correction is needed in the article by Molina et al. (Molina CA, Theodore N, Ahmed AK, et al. Augmented reality-assisted pedicle screw insertion: a cadaveric proof-of-concept study. J Neurosurg Spine. 2019;31(1):139-146).

For transparency, the following sentence has been added to the beginning of the Disclosures section.

This study was conducted in a private anatomical laboratory (Vista Labs; Baltimore, MD) and not conducted at or under the auspices of The Johns Hopkins University School of Medicine. 2020 .

The article has been corrected online as of April 10,

Camilo A. Molina, MD

The Johns Hopkins University School of Medicine, Baltimore, MD

INCLUDE WHEN CITING

Published online April 10, 2020; DOI: 10.3171/2020.3.SPINE181142a.

CAANS 2020, except where prohibited by US copyright law 